\title{
Synthesis and Crystal Structure of Bis(N'-(Pyridine-3-Carboxaldehyde) Isonicotinoylhydrazone) Zinc(II)
}

\author{
Sally-Judith E. Ntum¹, Conde Asseng Mariam², Evans N. Mainsah ${ }^{3}$, Peter T. Ndifon ${ }^{1 *}$ (D) \\ ${ }^{1}$ Department of Inorganic Chemistry, Faculty of Science, University of Yaoundé 1, Yaoundé, Cameroon \\ ${ }^{2}$ Department of Chemistry, Faculty of Science, University of Douala, Douala, Cameroon \\ ${ }^{3}$ Department of Chemistry, University of Buea, Buea, South West Region, Cameroon \\ Email: *pndifon@yahoo.com
}

How to cite this paper: Ntum, S.-J.E., Mariam, C.A., Mainsah, E.N. and Ndifon, P.T. (2020) Synthesis and Crystal Structure of Bis( $\mathrm{N}^{\prime}$-(Pyridine-3-Carboxaldehyde) Isonicotinoylhydrazone) Zinc(II). Open Journal of Inorganic Chemistry, 10, 25-38.

https://doi.org/10.4236/ojic.2020.103004

Received: June 9, 2020

Accepted: July 28, 2020

Published: July 31, 2020

Copyright (๑) 2020 by author(s) and Scientific Research Publishing Inc. This work is licensed under the Creative Commons Attribution International License (CC BY 4.0).

http://creativecommons.org/licenses/by/4.0/

\begin{abstract}
Zinc complexes of Schiff base ligands exhibit interesting properties which could be exploited for potential applications as catalysts and models for biochemical systems. In this study, we report of the synthesis of a new zinc Schiff base complex, bis(N'-(pyridine-3-carboxaldehyde) isonicotinoylhydrazone) zinc(II), which has been characterized by physico-chemical methods. The X-ray single crystal structure of the complex has also been determined. The Schiff base ligand is bonded to the metal in a monodentate manner, coordinating through the pyridine $\mathrm{N}$-atom, as shown from spectral studies. The crystal structure shows the zinc atom bonded to two Schiff bases and four aqua ligands, with each Schiff base ligand coordinating through its pyridine $\mathrm{N}$-atom forming a distorted octahedral $\mathrm{ZnN}_{2} \mathrm{O}_{4}$ complex. Two water molecules and two nitrate ions found in the crystal structure link the different monomers through hydrogen bonding to form a layered supramolecular structure.
\end{abstract}

\section{Keywords}

Zinc Complex, Heterocyclic Schiff Base, Isonicotinic Acid Hydrazide (Isoniazid), Hydrazone, X-Ray Structure, Spectroscopy

\section{Introduction}

There is a substantial increase in the coordination chemistry of zinc due to its structural diversity. Zinc(II) can form complexes with a flexible coordination environment with geometries ranging from tetrahedral, trigonal bipyramidal and square pyramidal to octahedral [1] [2] [3] [4]. Zinc(II) complexes have been 
found to play a variety of roles in living organisms, such as catalytic cofactor for a number of metalloenzymes, stabilizing protein structures and modulating the interactions between macromolecules [5] [6] [7].

Schiff bases are important as ligands because of their ease of preparation and their resemblance to natural biomolecules [8] [9]. Their metal complexes have been studied extensively because of their attractive physico-chemical properties and structural diversity, which account for their wide range of applications in industry and biology [9]-[13]. Zinc complexes of Schiff base ligands have received particular attention due to their ease of preparation, high thermal stability, photoluminescence properties and their potential applications as catalysts and model molecules for biochemical systems [10] [12] [14].

While Heterocyclic nitrogen containing compounds such as pyridine and its derivatives are present in many synthetic and natural systems, heterocyclic Schiff base ligands containing $\mathrm{O}-, \mathrm{N}$ - or S-donors and their metal complexes exhibit interesting properties [7] [15] [16]. The study of the structural chemistry of Schiff base ligands and their complexes is important in understanding the complex biological properties of these systems. Such ligands have been used to construct various metal-organic frameworks including coordination polymers due to their capabilities to act as chelators or connectors using the imine linkage [9] [17].

Our group recently embarked on studies on the biological activities of complexes of heterocyclic Schiff base ligands [13] [18]. The observed biological activities result from the presence of the characteristic azomethine $(-\mathrm{N}=\mathrm{CH}-)$ functionality of the Schiff base. One such class of heterocyclic Schiff base ligands are pyridinecarboxaldehyde isonicotinoyl hydrazones, derived from isoniazid (Isonicotinic acid hydrazide), which generally are bidentate or tridentate chelators and typically form six-coordinate complexes [19] [20] [21] [22]. We report here the synthesis, characterisation and X-ray single crystal structure of a zinc(II) complex of N'-(pyridine-3-carboxaldehyde)isonicotinoylhydrazone Schiff base ligand in which bonding to the zinc atom is through the $\mathrm{N}$-atom of pyridine while the imine group remains unusually uncoordinated.

\section{Experimental}

\subsection{Materials and Measurements}

All reagents were of analytical grade and were used without further purification. Elemental analyses $(\mathrm{C}, \mathrm{H}, \mathrm{N})$ were determined on a Thermo Scientific FLASH 2000 Organic Elemental CHNS-O Analyser. The metal content was determined using a Thermo Scientific iCAP 6000 SERIES duo ICAP spectrometer. ${ }^{1} \mathrm{H}-\mathrm{NMR}$ and ${ }^{13} \mathrm{C}$-NMR spectra were recorded on a Bruker 400c instrument. Thermogravimetric analysis was carried out on a Mettler Toledo TGA/DSC1 Star System. Infrared spectra were recorded on a Thermo Scientific Nicolet iS5 (iDR ATR) spectrometer. The UV/Vis spectrum was recorded on an Agilent HP8453 Diode Array UV/Vis spectrometer. The single crystal X-ray structure was determined 
on a Bruker APEX diffractometer.

\subsection{Synthesis of the Ligand, N'-(Pyridine-3-Carbaxaldehyde) Isonicotinoylhydrazone (L)}

The ligand was prepared by a slight modification of a previously published method [19] [20] as illustrated in Scheme 1. Pyridine-3-carboxaldehyde (10,711 g, $100 \mathrm{mmol}$ ), in methanol was added dropwise to a stirred solution of Isonicotinic acidhydrazide (isoniazid) (100 mmol, 13,711 g) in hot methanol and the mixture was heated under reflux for $3 \mathrm{~h}$. The resulting yellow precipitate was washed with hot methanol and dried in air at room temperature. Yield: $92 \%$. Mpt: $232^{\circ} \mathrm{C}-234^{\circ} \mathrm{C}$ Anal. Calc. for $\mathrm{C}_{12} \mathrm{H}_{10} \mathrm{~N}_{4} \mathrm{O}$ : C 63.71; $\mathrm{H} 4.46 ; \mathrm{N} 24.77$. Found C: 63.77, H 4.27, N, 24.80; IR (KBr/cm $\left.{ }^{-1}\right): 3182 w, 3005$ - 2833w, 1681vs, 1557vs; ${ }^{1} \mathrm{H}$ NMR (400 MHz, DMSO- $d_{6}$ ): $\delta$ ppm 7.50 (dd, $\left.7.89,4.80 \mathrm{~Hz}, 1 \mathrm{H}\right) 7.82$ (d, $J 6.00 \mathrm{~Hz}, 2 \mathrm{H}) 8.16(\mathrm{dt}, \pi .99,1.82 \mathrm{~Hz}, 1 \mathrm{H}) 8.51(\mathrm{~s}, 1 \mathrm{H}) 8.63(\mathrm{dd}, J 4.77,1.61 \mathrm{~Hz}$, $1 \mathrm{H}) 8.79$ (d, J6.00 Hz, $2 \mathrm{H}) 8.88$ (s, $1 \mathrm{H}) 12.20$ (br. s., $1 \mathrm{H})$.

\subsection{Synthesis of Bis(N'-(N'-(Pyridine-3-Carbaxaldehyde) Isonicotinoylhydrazone) $\mathrm{Zinc}(\mathrm{II})\left[\mathrm{ZnL}_{2}\left(\mathrm{H}_{2} \mathrm{O}\right) 4\right]\left(\mathrm{NO}_{3}\right)_{2} \cdot 2 \mathrm{H}_{2} \mathrm{O}$}

A well stirred solution of the ligand, $\mathrm{L}(0.904 \mathrm{~g}, 4 \mathrm{mmol})$ in aqueous mixture was added drop wise to a stirred solution of $\mathrm{Zn}\left(\mathrm{NO}_{3}\right)_{2} \cdot 6 \mathrm{H}_{2} \mathrm{O}(0.595 \mathrm{~g}, 2 \mathrm{mmol})$, dissolved in $2 \mathrm{~mL}$ of distilled water. The colourless solution of the metal salt turned yellow. The mixture was heated under reflux for $2 \mathrm{~h}$ and thereafter allowed to stand until the formation of light yellow crystals after two days. The crystals were filtered and dried in air. Yield: $40 \%$. Mpt: $127^{\circ} \mathrm{C}-129^{\circ} \mathrm{C}$. Anal. Calc. for $\mathrm{C}_{24} \mathrm{H}_{32} \mathrm{~N}_{10} \mathrm{O}_{14} \mathrm{Zn}$ : C 38.44; $\mathrm{H}$ 4.30; $\mathrm{N} 18.68 ; \mathrm{Zn} \mathrm{8.72}$. Found C 38.22; H 4.14; N 18.48; Zn 8.20. IR (KBr, cm ${ }^{-1}$ ): 3237br, 3237br, 3065 - 2973w, 1648s, 1557s.

${ }^{1} \mathrm{H}$ NMR (400 MHz, DMSO-d $\left.{ }_{6}\right): 12.30$ (2H, S, H(N3)), 8.89 (2H, S, H(C1), 8.80 (4H, d, J ${ }_{5.8} \mathrm{H}\left(\mathrm{C}(9), \mathrm{C}(12), \mathrm{C}\left(9^{\prime}\right), \mathrm{C}\left(12^{\prime}\right)\right)$, $8.64\left(2 \mathrm{H}, \mathrm{d}, \mathrm{J}_{3.8}\right), 8.51$ (2H, S, C(6)), $8.18\left(2 \mathrm{H}, \mathrm{d}, \mathrm{J}_{8.0}\right) 7.84\left(4 \mathrm{H}, \mathrm{d}, \mathrm{J}_{6} . \mathrm{C}(10), \mathrm{C}(11)\right), 7.52$ (2H, dd, J8. $\mathrm{J}_{4.9}, \mathrm{H}(\mathrm{C}(5), \mathrm{C}(3))$.

\subsection{Crystal Structure Determination}

A suitable pale yellow crystal of the title compound measuring about $0.14 \times 0.11$ $\times 0.05 \mathrm{~mm}^{3}$ was mounted using a glass fibre on the goniometer head of a Bruker APEX diffractometer and data were collected using graphite monochromated $\mathrm{Cu}-K_{\alpha}$ radiation $(\lambda=1.54178 \AA)$ at a temperature of $100 \mathrm{~K}$. The structure was solved by Direct Methods and refined by full-matrix least squares on $F^{2}$ [23]. All non-Hydrogen atoms were refined anisotropically. Hydrogen atoms were included in calculated positions, assigned isotropic displacement parameters and allowed to ride on their parent carbon atoms. All calculations were carried out using the SHELXTL package [24]. Table 1 presents the crystal data and refinement parameters; Table 2 lists the selected bond lengths and bond angles while Table 3 gives the hydrogen bond parameters. CCDC 1419801 contains the supplementary crystallographic data for this paper. This data can be obtained free of 
charge from the Cambridge Crystallographic Data Centre via

http://www.ccdc.cam.ac.uk/dada request/cif.<smiles>NNC(=O)c1ccncc1</smiles>

Isoniazid<smiles>O=Cc1cccnc1</smiles>

Pyridine-3-carboxaldehyde<smiles>O=C(N/N=C/c1ccncc1)c1cccnc1</smiles>

Scheme 1. Synthesis of N'-(pyridine-3-carbaxaldehyde) isonicotinoylhydrazone (L).

Table 1. Crystal data and structure refinement for $\left[\mathrm{ZnL}_{2}\left(\mathrm{H}_{2} \mathrm{O}\right)_{4}\right]\left(\mathrm{NO}_{3}\right)_{2} \cdot 2 \mathrm{H}_{2} \mathrm{O}$.

\begin{tabular}{|c|c|}
\hline Moiety formula & $\mathrm{C}_{24} \mathrm{H}_{28} \mathrm{~N}_{8} / \mathrm{O}_{6} \mathrm{Zn}^{\prime} 2\left(\mathrm{NO}_{3}\right) \cdot 2 \mathrm{H}_{2} \mathrm{O}$ \\
\hline Empirical formula & $\mathrm{C}_{24} \mathrm{H}_{32} \mathrm{~N}_{10} \mathrm{O}_{14} \mathrm{Zn}$ \\
\hline Formula weight & 749.99 \\
\hline Temperature & $100(2) \mathrm{K}$ \\
\hline Wavelength & $1.54178 \AA$ \\
\hline Crystal system & Triclinic \\
\hline Space group & $\mathrm{P}-1$ \\
\hline \multirow[t]{3}{*}{ Unit cell dimensions } & $\mathrm{a}=7.1352(2) \AA \alpha=82.2320(10)^{\circ}$. \\
\hline & $\mathrm{b}=10.0806(3) \AA \beta=78.3580(10)^{\circ}$. \\
\hline & $\mathrm{c}=11.3575(3) \AA \gamma=77.7330(10)^{\circ}$. \\
\hline Volume & $778.20(4) \AA^{3}$ \\
\hline $\mathrm{Z}$ & 1 \\
\hline Density (calculated) & $1.6 \mathrm{~g} / \mathrm{cm}^{3}$ \\
\hline Absorption coefficient & $1.857 \mathrm{~mm}^{-1}$ \\
\hline $\mathrm{F}(000)$ & 388 \\
\hline Crystal size & $0.21 \times 0.09 \times 0.03 \mathrm{~mm}^{3}$ \\
\hline Theta range for data collection & 3.99 to $72.07^{\circ}$. \\
\hline Index ranges & $-8 \leq \mathrm{h} \leq 8,-12 \leq \mathrm{k} \leq 12,-13 \leq \mathrm{l} \leq 14$ \\
\hline Reflections collected & 8067 \\
\hline Independent reflections & $2962[\mathrm{R}(\mathrm{int})=0.0199]$ \\
\hline Completeness to theta $=67.00^{\circ}$ & $97.4 \%$ \\
\hline Absorption correction & Semi-empirical from equivalents \\
\hline Max. and min. transmission & 0.9464 and 0.761667 \\
\hline Refinement method & Full-matrix least-squares on $\mathrm{F}^{2}$ \\
\hline Data/restraints/parameters & $2962 / 0 / 251$ \\
\hline Goodness-of-fit on $\mathrm{F}^{2}$ & 1.037 \\
\hline Final R indices $[\mathrm{I}>2 \operatorname{sigma}(\mathrm{I})]$ & $\mathrm{R} 1=0.0279, \mathrm{wR} 2=0.0725$ \\
\hline $\mathrm{R}$ indices (all data) & $\mathrm{R} 1=0.0303, \mathrm{wR} 2=0.0740$ \\
\hline Largest diff. peak and hole & 0.43 and -0.22 e. $\AA^{-3}$ \\
\hline
\end{tabular}


Table 2. Selected Bond lengths $[\AA ̊]$ and Bond angles [ $\left.{ }^{\circ}\right]$ for $\left[\mathrm{ZnL}_{2}\left(\mathrm{H}_{2} \mathrm{O}\right)_{4}\right]\left(\mathrm{NO}_{3}\right)_{2} \cdot 2 \mathrm{H}_{2} \mathrm{O}$.

\begin{tabular}{|c|c|}
\hline Bond lengths $[\AA]$ & \\
\hline C1 - N1 1.340(2) & N2 - N3 1.3776(19) \\
\hline $\mathrm{C} 1$ - C2 1.388(2) & N3 - H3B 0.89(3) \\
\hline C1 - H1 0.9500 & N5 - O3 1.2287(19) \\
\hline C4 - C5 1.384(2) & N5 - O4 1.259(2) \\
\hline C5 - N1 1.345(2) & O5 - Zn1 2.0738(12) \\
\hline $\mathrm{C} 7$ - O1 1.232(2) & O5 - H5B 0.79(3) \\
\hline C7 - N3 1.340(2) & O6 - Zn1 2.1249(11) \\
\hline C11 - N4 1.333(2) & Zn1 - N1 2.1510(14) \\
\hline C11- C12 1.390(2) & Zn1 - O6 2.1249(11) \\
\hline \multicolumn{2}{|l|}{ Bond angles $\left[{ }^{\circ}\right]$} \\
\hline N1 - C1 - C2 123.47(15) & O5 - Zn1 - O6 90.33(5) \\
\hline C1 - C2 - C3 117.84(15) & O5 - Zn1 - O6 90.33(5) \\
\hline C1 - C2 - C6 118.61(15) & O6 - Zn1 - O6 179.999(1) \\
\hline C5 - C4 - H4 120.4 & O5 - Zn1 - N1 89.17(5) \\
\hline N1 - C5 - C4 122.66(15) & O5 - Zn1 - N1 90.83(5) \\
\hline N1 - C5 - H5 118.7 & O6 - Zn1 - N1 90.42(5) \\
\hline O1 - C7 - N3 123.12(15) & O6 - Zn1 - N1 89.58(5) \\
\hline O1 - C7 - C8 120.86(15) & O5 - Zn1 - N1 90.83(5) \\
\hline C1 - N1 - C5 117.76(14) & O5 - Zn1 - N1 89.17(5) \\
\hline C1 - N1 - Zn1 119.83(11) & O6 -Zn1 - N1 89.58(5) \\
\hline Zn1 - O5 - H5A 117.1(18) & O6 -Zn1 - N1 90.42(5) \\
\hline O5 - Zn1 - O5 180.0 & N1 -Zn1 - N1 180.00(5) \\
\hline
\end{tabular}

Table 3. Hydrogen bond Parameters for $\left[\mathrm{ZnL}_{2}\left(\mathrm{H}_{2} \mathrm{O}\right)_{4}\right]\left(\mathrm{NO}_{3}\right)_{2} \cdot 2 \mathrm{H}_{2} \mathrm{O}$.

\begin{tabular}{ccccc}
\hline $\mathrm{D}-\mathrm{H} \ldots \mathrm{A}$ & $\mathrm{d}(\mathrm{D}-\mathrm{H})$ & $\mathrm{d}(\mathrm{H} \ldots \mathrm{A})$ & $\mathrm{d}(\mathrm{D} \ldots \mathrm{A})$ & $<($ DHA $)$ \\
\hline $\mathrm{O}(6)-\mathrm{H}(6 \mathrm{~A}) \ldots \mathrm{O}(1) \# 2$ & $0.76(3)$ & $1.96(3)$ & $2.7126(17)$ & $176(3)$ \\
$\mathrm{O}(5)-\mathrm{H}(5 \mathrm{~B}) \ldots \mathrm{N}(4) \# 3$ & $0.79(3)$ & $1.92(3)$ & $2.7079(18)$ & $177(3)$ \\
$\mathrm{O}(7)-\mathrm{H}(7 \mathrm{~B}) \ldots \mathrm{O}(2)$ & $0.84(3)$ & $1.92(3)$ & $2.7613(18)$ & $179(2)$ \\
$\mathrm{O}(5)-\mathrm{H}(5 \mathrm{~A}) \ldots \mathrm{O}(7) \# 1$ & $0.83(3)$ & $2.01(3)$ & $2.8286(18)$ & $171(2)$ \\
$\mathrm{N}(3)-\mathrm{H}(3 \mathrm{~B}) \ldots \mathrm{O}(4) \# 4$ & $0.89(3)$ & $2.16(3)$ & $3.040(2)$ & $168(2)$ \\
$\mathrm{O}(6)-\mathrm{H}(6 \mathrm{~B}) \ldots \mathrm{O}(7) \# 5$ & $0.79(3)$ & $1.96(3)$ & $2.7442(18)$ & $170(3)$ \\
$\mathrm{O}(7)-\mathrm{H}(7 \mathrm{~A}) \ldots \mathrm{O}(1) \# 6$ & $0.87(3)$ & $2.00(3)$ & $2.7312(18)$ & $141(3)$ \\
\hline
\end{tabular}

\section{Results and Discussion}

The ligand, N'-(pyridine-3-carboxaldehyde) isonicotinoylhydrazone (L), was obtained from the condensation reaction between isoniazid and pyridine-3-carboxaldehyde in methanol to give a yellow precipitate. The precipitate is stable in air, soluble in DMSO and in hot aqueous alcohol. The reaction of $\mathrm{N}^{\prime}$-(pyridine3-carboxaldehyde)isonicotinoylhydrazone and $\mathrm{Zn}\left(\mathrm{NO}_{3}\right)_{2} \cdot 6 \mathrm{H}_{2} \mathrm{O}$ in a 2:1 molar 
ratio, in aqueous methanol mixture yielded a pale yellow powder and pale yellow rectangular-shaped crystals of $\left[\mathrm{ZnL}_{2}\left(\mathrm{H}_{2} \mathrm{O}\right)_{4}\right]\left(\mathrm{NO}_{3}\right)_{2} \cdot 2 \mathrm{H}_{2} \mathrm{O}$ extracted from the filtrate. Both the precipitate and the crystals are stable in air. The crystals are soluble in DMSO and aqueous alcohol.

${ }^{1} \mathrm{H}$-NMR spectra were recorded in DMSO- $d_{6}$ at $400 \mathrm{MHz}$ to explore the variations of chemical shifts between the ligand and its complex. The ${ }^{1} \mathrm{H}-\mathrm{NMR}$ signals of the complex are shifted to higher frequencies as compared to that of the ligand (Figure 1). However, the resonance at $8.51 \mathrm{ppm}$, attributed to the proton at the $\mathrm{N}=\mathrm{CH}$ imine functional group is the same in both the ligand and the zinc complex, thus indicating that the imine group does not participate in bonding.

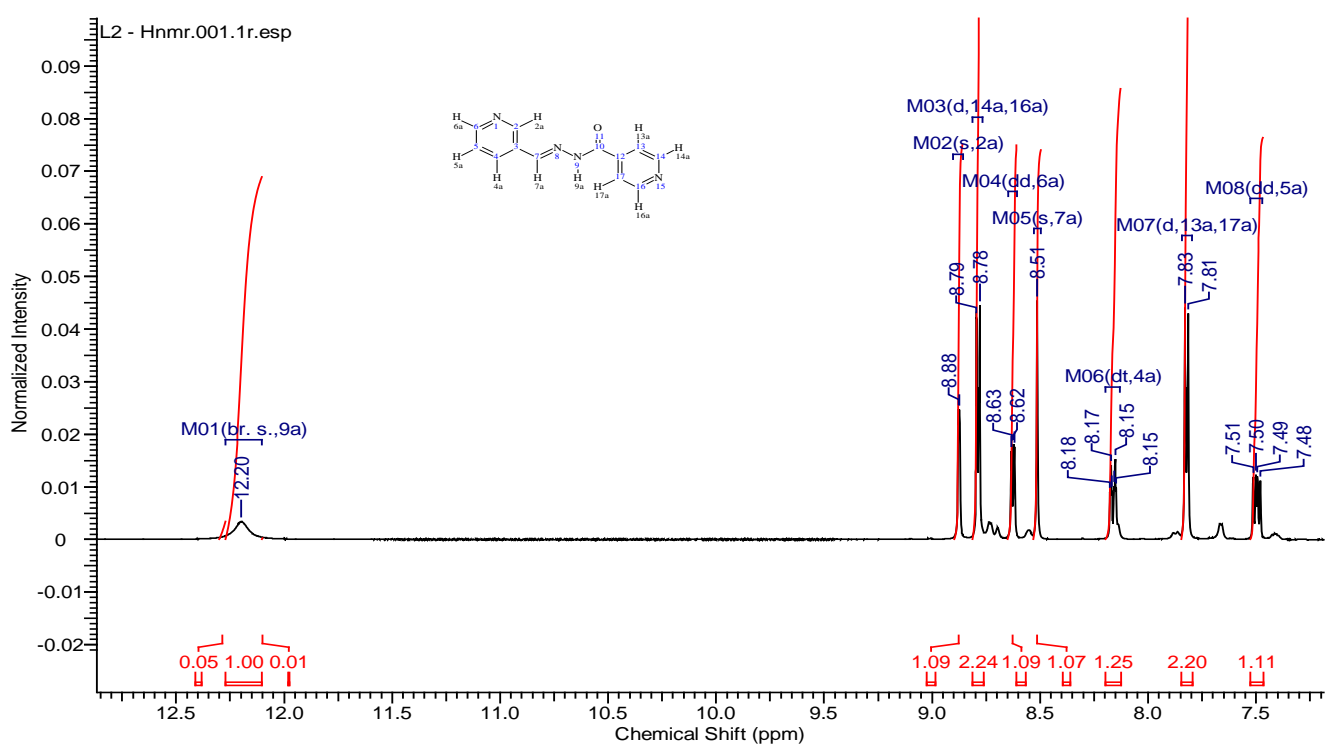

(a)

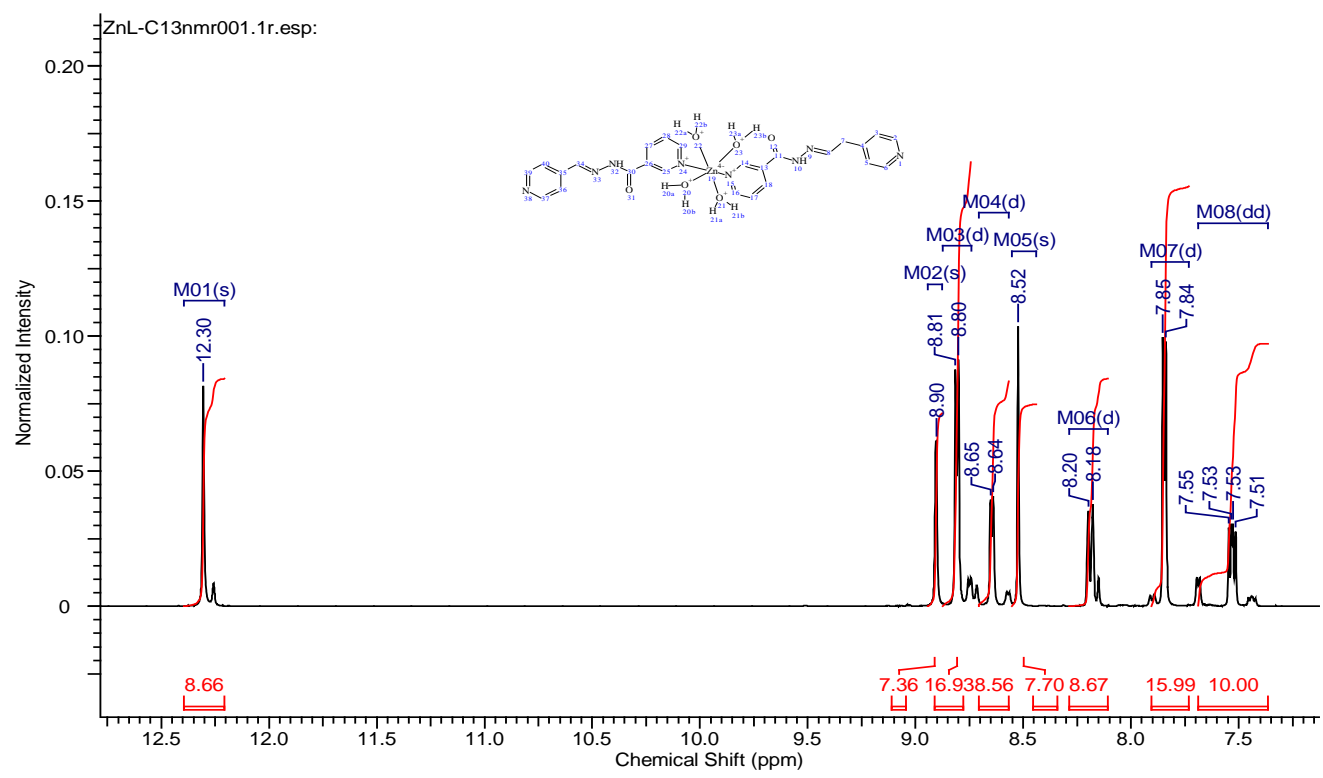

(a)

Figure 1. (a) ${ }^{1} \mathrm{H}$ NMR of $\mathrm{L}$; (b) ${ }^{1} \mathrm{H}$ NMR of $\left[\mathrm{ZnL}_{2}\left(\mathrm{H}_{2} \mathrm{O}\right) 4\right]\left(\mathrm{NO}_{3}\right)_{2} \cdot 2 \mathrm{H}_{2} \mathrm{O}$. 
The ${ }^{13} \mathrm{C}$ NMR spectrum of the free ligand displays a set of ten peaks due to the free rotation of the hydrazone arm (Figure $2(\mathrm{a})$ ). The ${ }^{13} \mathrm{C}$ NMR spectrum of the complex shows a set of ten peaks, suggesting a symmetrical structure (Figure 2(b)). Moreover, a comparison of the spectrum of the free ligand with that of the zinc complex shows a shift in the resonances towards higher chemical shifts upon coordination to the metal centre. This shift is even more intense for the carbon atom in the para position to the nitrogen atom of the pyridine ring. Such variations can be explained by the decrease of the shielding effect of the nitrogen atom. Therefore, all these observations fit and confirm the model where the zinc atom binds through the nitrogen atom of the pyridine, and where the imine group does not participate in bonding.

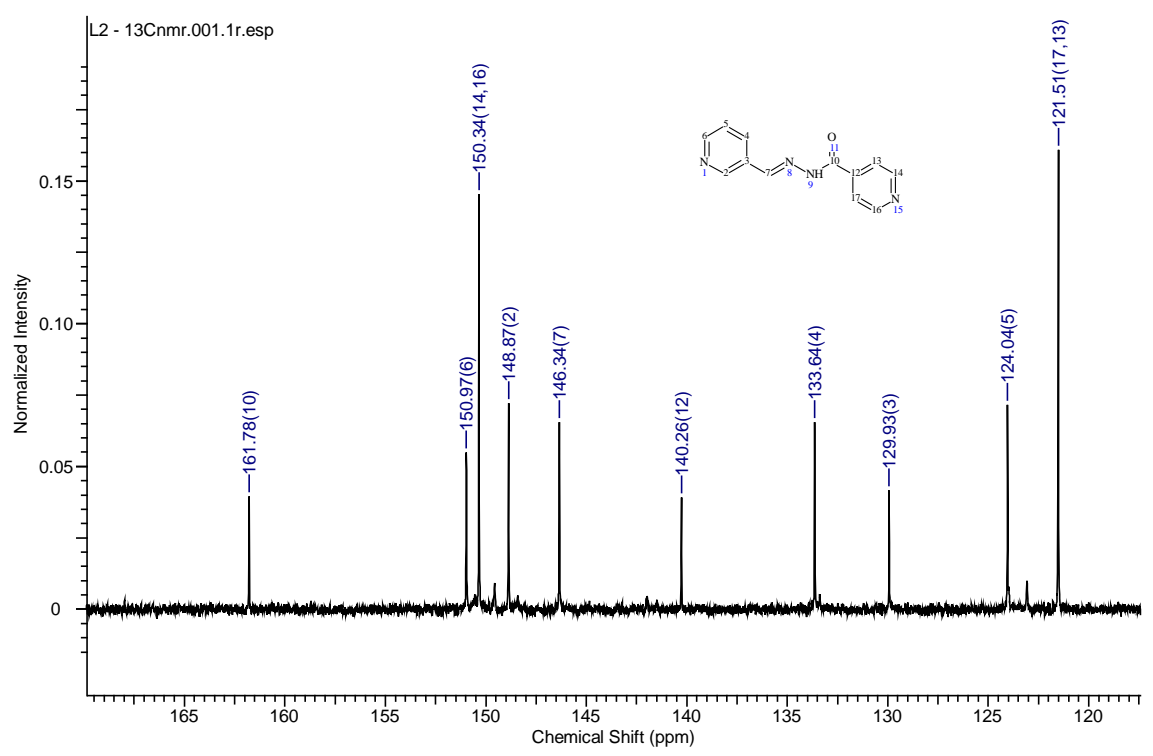

(a)

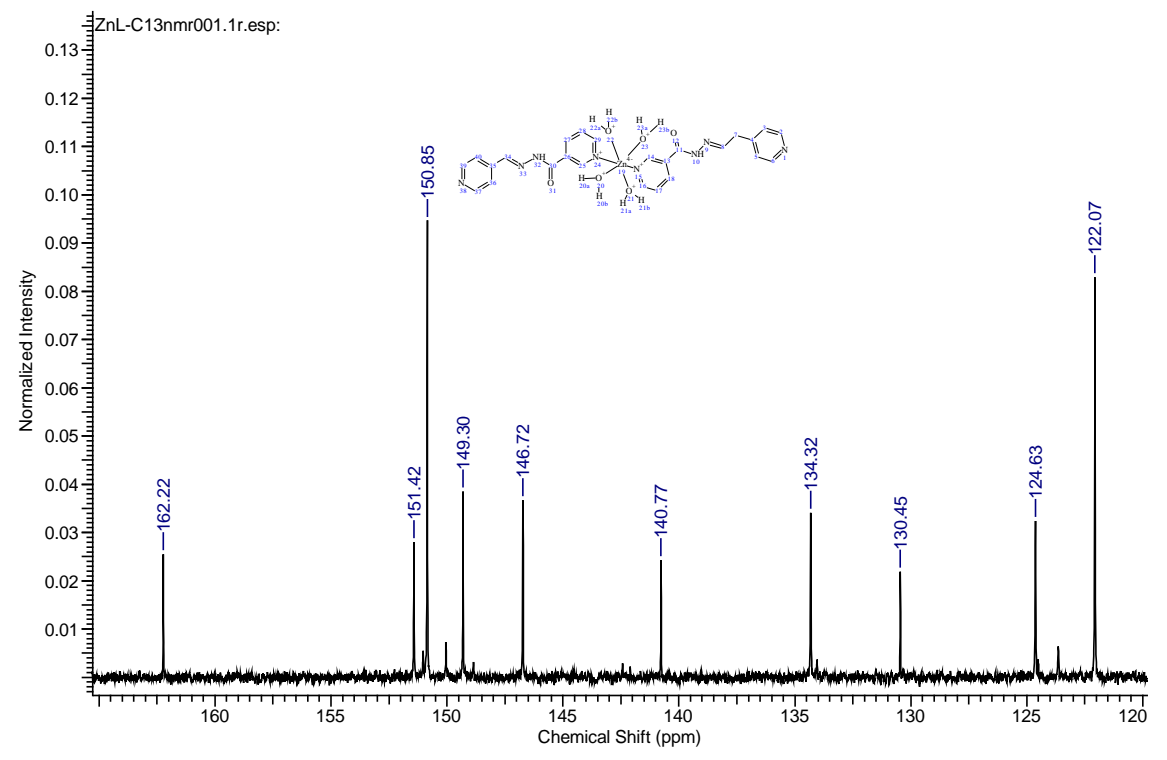

(b)

Figure 2. (a) ${ }^{13} \mathrm{C}$ NMR of $\mathrm{L}$; (b) ${ }^{13} \mathrm{C}$ NMR of $\left[\mathrm{ZnL}_{2}\left(\mathrm{H}_{2} \mathrm{O}\right)_{4}\right]\left(\mathrm{NO}_{3}\right)_{2} \cdot 2 \mathrm{H}_{2} \mathrm{O}$. 
The IR spectrum of the ligand ( $\mathrm{L})$ and that of the $\mathrm{ZnL}_{2}$ complex show a broad peak at $3237 \mathrm{~cm}^{-1}$ attributed to $v(\mathrm{O}-\mathrm{H})$ of water molecules in the complex which is clearly absent in the spectrum of the ligand (Figure 3). The peak at $3183 \mathrm{~cm}^{-1}$ corresponds to $v(\mathrm{~N}-\mathrm{H})$ stretching of the ligand. This peak is found to merge with the $v(\mathrm{O}-\mathrm{H})$ band in the spectrum of the complex due to hydrogen bonding [25]. The $v(=\mathrm{C}-\mathrm{H})$ band of the pyridyl ring is observed in the range of 3005 $2833 \mathrm{~cm}^{-1}$. These bands are seen to shift to higher frequencies in the spectrum of the complex. The $v(\mathrm{C}=\mathrm{O})$ band is seen to shift to a lower frequency in the spectrum of the complex due to extended conjugation with the nearby pyridine ring [10] [15]. The $v(\mathrm{C}=\mathrm{N})$ band is observed at about the same position in both spectra indicating that this unit does not participate in bonding.

The UV/Vis absorption spectrum of the compounds was recorded at room temperature in DMSO as shown in Figure 4. The ligand exhibits a band at 301 $\mathrm{nm}$, which is attributed to $\pi-\pi^{*}$ transitions of the pyridyl rings. On the other hand, the spectrum of the $\mathrm{ZnL}_{2}$ complex exhibits two bands. The first band at $277 \mathrm{~nm}$ corresponding to $\pi-\pi^{*}$ transitions of the pyridyl ring while the second band at $346 \mathrm{~nm}$ is attributed to a metal-to-ligand charge transfer transitions (MLCT). No absorption peaks were observed in the visible region as expected for a $\mathrm{d}^{10}$ system.

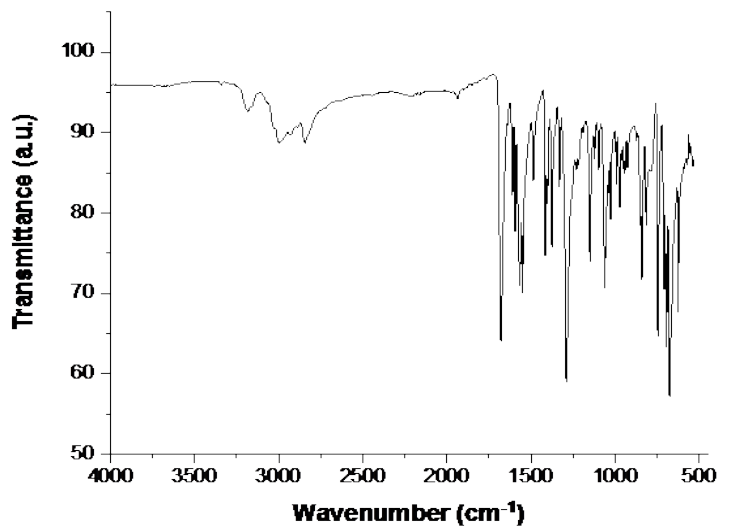

(a)

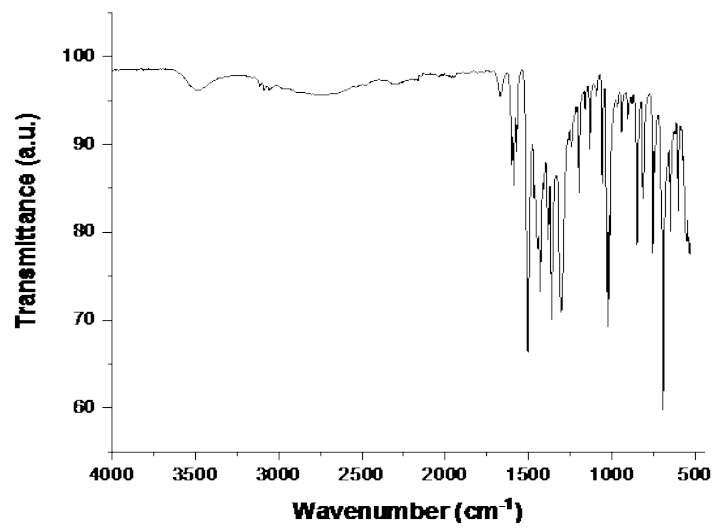

(b)

Figure 3. (a) IR Spectrum of the Schiff base ligand (L); (b) IR Spectrum of $\left[\mathrm{ZnL}_{2}\left(\mathrm{H}_{2} \mathrm{O}\right)_{4}\right]\left(\mathrm{NO}_{3}\right)_{2} \cdot 2 \mathrm{H}_{2} \mathrm{O}$. 


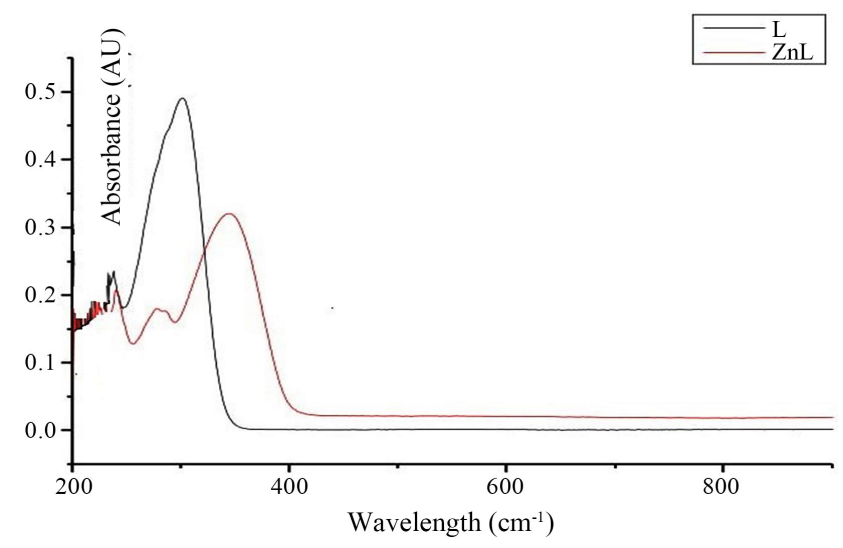

Figure 4. UV/Vis Spectrum of $\mathrm{L}$ and $\left[\mathrm{ZnL}_{2}\left(\mathrm{H}_{2} \mathrm{O}\right)_{4}\right]\left(\mathrm{NO}_{3}\right)_{2} \cdot 2 \mathrm{H}_{2} \mathrm{O}$.

\subsection{Thermal Analysis}

The thermal behaviour of $\left[\mathrm{ZnL}_{2}\left(\mathrm{H}_{2} \mathrm{O}\right) 4\right]\left(\mathrm{NO}_{3}\right)_{2} \cdot 2 \mathrm{H}_{2} \mathrm{O}$ is shown in Figure 5 and represents the TGA thermogram recorded under nitrogen atmosphere in the temperature range of $30^{\circ} \mathrm{C}$ to $600^{\circ} \mathrm{C}$ at a heating rate of $25^{\circ} \mathrm{C} \cdot \mathrm{min}^{-1}$ and consists of a three-step decomposition process. The first decomposition of $4.59 \%$ (calc. $4.8 \%)$ at $126.4^{\circ} \mathrm{C}$ is attributed to the loss of the two molecules of the water of crystallization. The second step at $139.3^{\circ} \mathrm{C}$ represents to the loss $10.4 \%$ (calc. $10.1 \%)$ corresponding to the decomposition of the two nitrate ions. The loss at $298.2^{\circ} \mathrm{C}$ of $67.9 \%$ (calc. $68.6 \%$ ) is attributed to the decomposition of the two ligand molecules and one water molecule. The residue of $17.5 \%$ which starts appearing at $350^{\circ} \mathrm{C}$ probably corresponds to the decomposition of the remaining water molecule to leave a solid mixture which includes zinc oxide.

\subsection{Scanning Electron Micrographs (SEM)}

The surface morphology of materials is important for technical applications requiring well-defined surface or interfaces. The SEM images of the Schiff base ligand (Figure 6(a)) reveal a non-homogenous morphology of irregular particles of different sizes and shapes. The particle sizes range from $31.10-141.3 \mu \mathrm{m}$. The $\left[\mathrm{Zn}\left(\mathrm{L}_{2}\right)_{2}\left(\mathrm{H}_{2} \mathrm{O}\right)_{4}\right]\left(\mathrm{NO}_{3}\right) 2 \cdot 2 \mathrm{H}_{2} \mathrm{O}\left(\mathrm{ZnL}_{2}\right)$ complex displays loosely packed particles of different sizes and shape ranging from $503.5 \mathrm{~nm}-2.04 \mu \mathrm{m}$ (Figure 6(b)).

\subsection{Crystal Structure of $\left[\mathrm{ZnL}_{2}\left(\mathrm{H}_{2} \mathrm{O}\right)_{4}\right]\left(\mathrm{NO}_{3}\right)_{2} \cdot 2 \mathrm{H}_{2} \mathrm{O}$}

The ORTEP drawing of $\left[\mathrm{ZnL}_{2}\left(\mathrm{H}_{2} \mathrm{O}\right)_{4}\right]\left(\mathrm{NO}_{3}\right)_{2} \cdot 2 \mathrm{H}_{2} \mathrm{O}$ showing its structure together with the atom numbering scheme is depicted in Figure 7. $\left[\mathrm{Zn}\left(\mathrm{L}_{2}\right)_{2}\left(\mathrm{H}_{2} \mathrm{O}\right)_{4}\right]$ $\left(\mathrm{NO}_{3}\right) 2 \cdot 2 \mathrm{H}_{2} \mathrm{O}$ has a symmetrical structure that crystallizes in the triclinic system with space group, $P-1$ as shown in Table 1 . There is one crystallographically independent $\mathrm{Zn}(\mathrm{II})$ ion, two $\mathrm{N}$ '-(pyridine-3-carboxaldehyde) isonicotinoylhydrazone ligands, as well as four coordinated water molecules, in the symmetric unit. The important bond distances and angles are given in Table 2. The hydrogen bond parameters are given in Table 3. The molecular structure of the complex shows the zinc atom bonded to two molecules of $\mathrm{N}^{\prime}$-(pyridine-3-carboxalde- 
hyde)isonicotinoylhydrazone Schiff base and four aqua ligands, with each Schiff base coordinating through its pyridine $\mathrm{N}$-atom to form a distorted octahedral $\mathrm{ZnN}_{2} \mathrm{O}_{4}$ complex. The zinc(II) atom is therefore bonded to $\mathrm{N} 1$ of one ligand and the symmetry-related $\mathrm{N} 1 \mathrm{~A}$ of the other ligand and four oxygen atoms from the water molecules (O5, O5A, O6, O6A), giving a hexa-coordination around the $\mathrm{Zn}$ (II) center. The intermolecular hydrogen bond interactions in the complex are presented in Table 3. The coordination network is stabilized by intermolecular hydrogen bonding $(\mathrm{O}-\mathrm{H} \ldots \mathrm{O}-\mathrm{N}-\mathrm{O} \ldots$ $\mathrm{H}-\mathrm{O})$, resulting from two nitrates and two water molecules in the crystal lattice (Figure 8) [16]. This intermolecular hydrogen bond interaction leads to self-assembly of monomeric cores to form a supramolecular structure as presented in the packing diagram in Figure 9. The monomer of one complex therefore is linked to the monomer of another complex through intermolecular hydrogen bonding, involving coordinated water ligands and uncoordinated nitrates as shown in Figure 2. The two nitrate anions in the crystal structure neutralize the charge of $\mathrm{Zn}(\mathrm{II})$ ions.

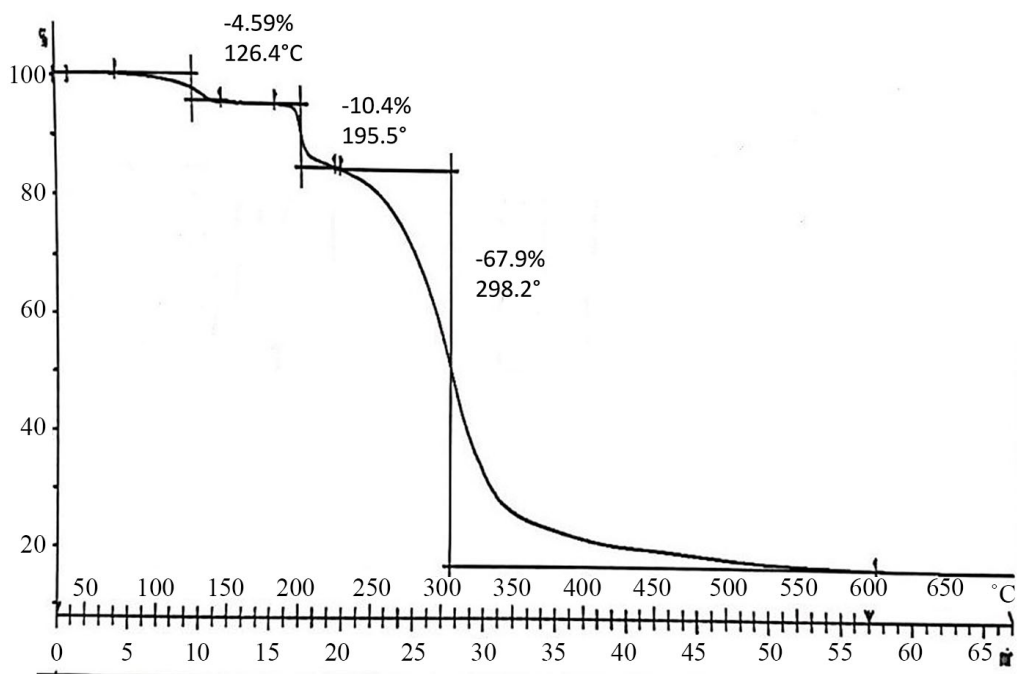

Figure 5. TGA thermogram of $\left[\mathrm{Zn}\left(\mathrm{L}_{2}\right)_{2}\left(\mathrm{H}_{2} \mathrm{O}\right)_{4}\right]\left(\mathrm{NO}_{3}\right) 2 \cdot 2 \mathrm{H}_{2} \mathrm{O}\left(\mathrm{ZnL}_{2}\right)$ Complex.

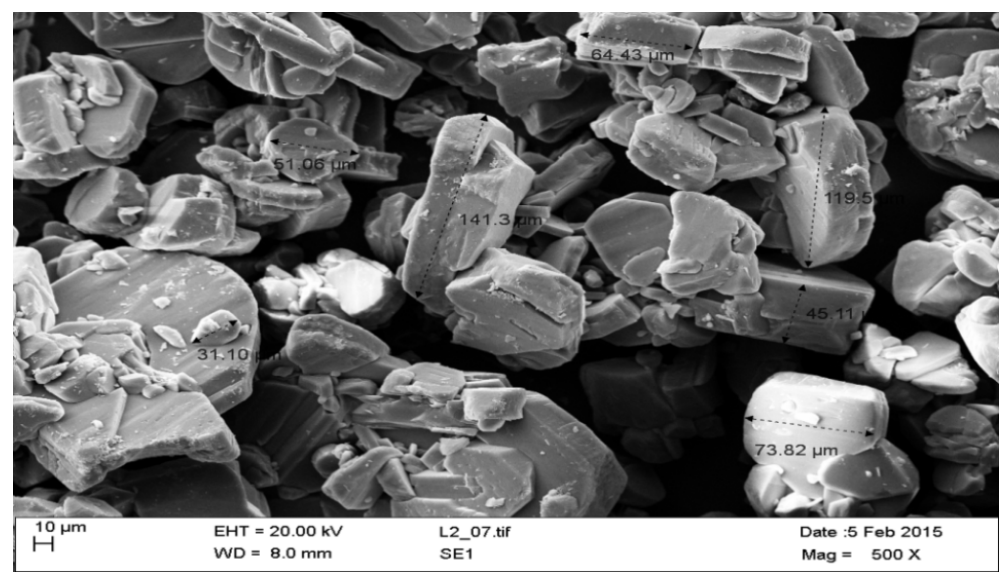

(a) 


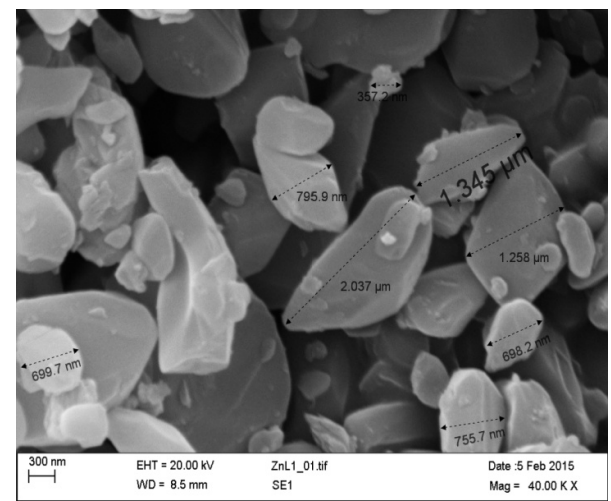

(b)

Figure 6. (a) SEM images of the ligand L; (b) SEM images of $\left[\mathrm{Zn}\left(\mathrm{L}_{2}\right)_{2}\left(\mathrm{H}_{2} \mathrm{O}\right)_{4}\right]\left(\mathrm{NO}_{3}\right) 2 \cdot 2 \mathrm{H}_{2} \mathrm{O}$.

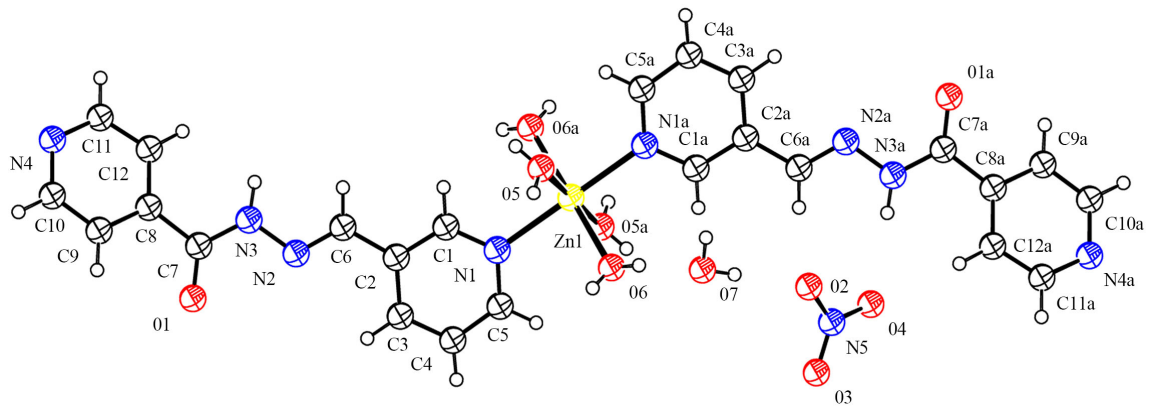

Figure 7. Ortep diagram of the molecular structure of $\left[\mathrm{ZnL}_{2}\left(\mathrm{H}_{2} \mathrm{O}\right)_{4}\right]\left(\mathrm{NO}_{3}\right)_{2} \cdot 2 \mathrm{H}_{2} \mathrm{O}$.

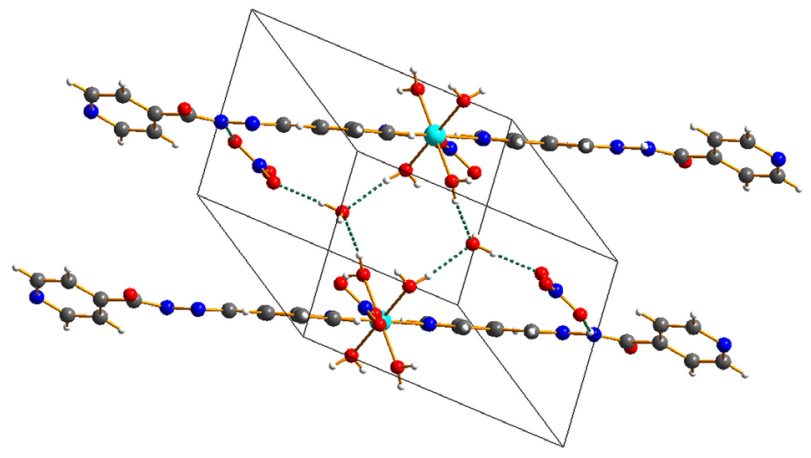

Figure 8. Diagram showing hydrogen bonding in $\left[\mathrm{ZnL}_{2}\left(\mathrm{H}_{2} \mathrm{O}\right)_{4}\right]\left(\mathrm{NO}_{3}\right)_{2} \cdot 2 \mathrm{H}_{2} \mathrm{O}$.

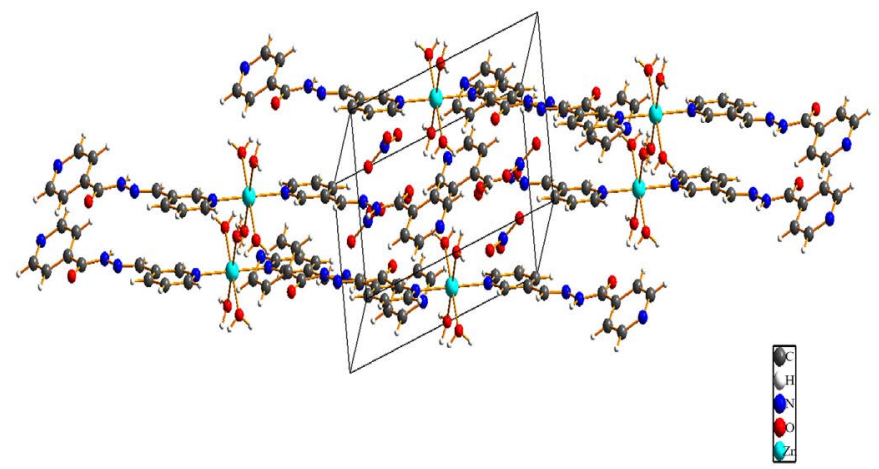

Figure 9. Packing diagram of $\left[\mathrm{ZnL}_{2}\left(\mathrm{H}_{2} \mathrm{O}\right)_{4}\right]\left(\mathrm{NO}_{3}\right)_{2} \cdot 2 \mathrm{H}_{2} \mathrm{O}$. 
The bond lengths ( $\mathrm{Zn}-\mathrm{N}$ of $2.151 \AA$ and $\mathrm{Zn}-\mathrm{O}$ of $2.0738-2.125 \AA$ ) and the bond angles ( $\mathrm{N}-\mathrm{Zn}-\mathrm{N}$ of $180^{\circ}$ and $\mathrm{O}-\mathrm{Zn}-\mathrm{O}$ of $180^{\circ}$ by symmetry) are close to values obtained for similar octahedral zinc(II) complexes [26]. The bonding of $\mathrm{N}$ '-(pyridine-3-carboxaldehyde) isonicotinoylhydrazone to zinc is in contrast to similar metal(II)-pyridine substituted isonicotinoylhydrazone schiff base complexes, which form typically 4- or 6-coordinate complexes in which each Schiff base ligand is coordinated through its pyridine $\mathrm{N}$-atom, imine $\mathrm{N}$-atom and carboxylate O-atom [20] [21] [22].

\section{Conclusion}

We have isolated a metal-organic framework from a pyridine-containing heterocyclic Schiff base ligand. The ${ }^{1} \mathrm{H}-\mathrm{NMR}$ and ${ }^{13} \mathrm{C}-\mathrm{NMR}$ spectra of this zinc(II) complex, show the symmetric nature of the complex in which the Schiff base is coordinated to the zinc atom through the pyridine nitrogen, thus forming a head-on, N-Zn-N system. This is confirmed by the X-ray structure of the complex. The imine (-N=CH-) groups remain unusually uncoordinated.

\section{Acknowledgements}

The authors thank Dr. James Raftery of the University of Manchester for assistance with the single crystal $\mathrm{x}$-ray structure determination.

\section{Conflicts of Interest}

The authors declare no conflicts of interest regarding the publication of this paper.

\section{References}

[1] Erxleben, A. and Helmans, J. (2000) Di- and Poly-Nuclear Zinc(II) Schiff Base Complexes: Synthesis, Structural Studies and Reaction with a-Amino Acid Esther. Journal of the Chemical Society, Dalton Transactions, No. 4, 569-575. https://doi.org/10.1039/a907839h

[2] Han, L.-L., Hu, T.-P., Mei, K., Guo, Z.-M., Yin, C., Wang, Y.-X., Zheng, J., Wang, X.-P. and Sn, D. (2015) Solvent-Controlled Three Families of Zn(II) Coordination Compounds: Synthesis, Crystal Structure, Solvent-Induced Structural Transformation, Supramolecular Isomerism and Photoluminescence. Dalton Transactions, 44, 6052-6061. https://doi.org/10.1039/C4DT03868A

[3] Sun, X.X., Qi, C.M., Ma, S.L., Huang, H.B., Zhu, W.X. and Liu, Y.C. (2006) Synthesis and Structure of $\mathrm{Zn}(\mathrm{II})$ Complexes Pentadetate Schiff-Base Ligands. Inorganic Chemistry Communications, 9, 911-914. https://doi.org/10.1016/j.inoche.2006.05.018

[4] Lipscomb, W.N. and Strater, N. (1996) Recent Advances of Zinc Enzymylogy. Chemical Reviews, 96, 2375-2433. https://doi.org/10.1021/cr950042j

[5] Vallee, B.L. and Auld, D.S. (1993) Zinc Biological Functional Coordination Motifs. Accounts of Chemical Research, 26, 543-551. https://doi.org/10.1021/ar00034a005

[6] Cuerva, C., Ovejero, P., Campo, J.A. and Cano, M. (2014) Tetrahedral and Octahedral Metallomesogenic Zn(II) Complexes Supported by Pyridine-Functionalised 
Pyrazole Ligands. New Journal of Chemistry, 38, 511-517. https://doi.org/10.1039/C3NJ00755C

[7] Nair, M.S., Arish, D. and Joseyphus, R.S. (2012) Synthesis, Characterization, Antifungal, Antibacterial and DNA Cleavage Studies of Some Heterocyclic Schiff Base Metal Complexes. Journal of Saudi Chemical Society, 16, 83-88.

https://doi.org/10.1016/j.jscs.2010.11.002

[8] Abu-Dief, A.M. and Mohamed, I.M.A. (2015) A Review on Versatile Applications of Transition Metal Complexes Incorporating Schiff Bases. Beni-Suef University Journal of Basic and Applied Sciences, 4, 119-133. https://doi.org/10.1016/j.bjbas.2015.05.004

[9] Cozzi, P.G. (2004) Metal-Salen Schiff Base Complexes in Catalysis: Practical Aspects. Chemical Society Reviews, 33, 410-421. https://doi.org/10.1039/B307853C

[10] Das, L.K., Gomez-Garcia, C.J. and Ghosh, A. (2015) Influence of the Central Metal Ion in Controlling the Self-Assembly and Magnetic Properties of 2D Coordination Polymers Derived from $[(\mathrm{NiL}) 2 \mathrm{M}] 2+$ Nodes $(\mathrm{M}=\mathrm{Ni}, \mathrm{Zn}$ and $\mathrm{Cd})(\mathrm{H} 2 \mathrm{~L}=$ Salen-Type Di-Schiff Base) and Dicynamide Spacers. Dalton Transactions, 44, 1292-1302. https://doi.org/10.1039/C4DT02823F

[11] Ndifon, P.T., Agwara, M.O., Njapa, J.N., Yufenyi, D.M., Papoudam, A.G. and Nyamen, L.D. (2010) Synthesis Characterisation and Antimicrobial Activity of $\mathrm{Cu}(\mathrm{II})$ and $\mathrm{Zn}$ (II) Complexes of Schiff Bases Derived from Amino Acids and 1,10-Phenanthroline Mixed Ligands. Research Journal of Chemistry and Environment, 14, 50-54.

[12] Selwin Josyphus, R. and Sivasankaran, N. (2008) Antobacteria and Antifungal Studies of Some Schiff Base Complexes of Zinc(II). Mycobiology, 36, 93-98.

https://doi.org/10.4489/MYCO.2008.36.2.093

[13] Mainsah, E.N., Ndifon, P.T., Nfor, E.N. and Njapba, J.N. (2013) Synthesis, Characterization and Antibacterial Properties of Some Transition Metal Complexes of (1H-pyrrol-2-yl)-isonicotinoylhydrazone. Bulletin of the Chemical Society of Ethiopia, 27, 395-404. https://doi.org/10.4314/bcse.v27i3.8

[14] Bhattargee, C.R., Das, G., Mondal, P. and Rao, N.V.S. (2010) Novel Photoluminescent Hemi-Disclike Liquid Crystalline $\mathrm{Zn}$ (II) Complexes of $\left[\mathrm{N}_{2} \mathrm{O}_{2}\right]$ Donor 4-Alkoxy Substituted Salicyldimine Schiff Base with Aromatic Spacer. Polyhedron, 29, 3089-3096. https://doi.org/10.1016/j.poly.2010.08.017

[15] Tripathi, S., Srirambalaji, R., Singh, N. and Anantharaman, G. (2014) Chiral and Achiral Helical Coordination Polymers of Zinc and Cadmium from Achiral 2,6-Bis(imidazol-1-yl) Pyridine: Solvent Effect and Spontaneous Resolution. Journal of Chemical Sciences, 126, 1423-1431. https://doi.org/10.1007/s12039-014-0650-8

[16] Siddiqui, K.A. (2013) C-H... $O_{\text {nitrate }}$ Synthon Assisted Molecular Assembly of Hydrogen Bonded $\mathrm{Ni}(\mathrm{II})$ and $\mathrm{Cu}(\mathrm{II})$ Complexes. Journal of Coordination Chemistry, 66, 2039-2050. https://doi.org/10.1080/00958972.2013.797967

[17] Ye, B.-H., Tong, M.-L. and Chen, X.-M. (2005) Metal-Organic Molecular Architectures with 2,2'-Bipyridyl-like and Carboxylate Ligands. Coordination Chemistry Reviews, 249, 545-565. https://doi.org/10.1016/j.ccr.2004.07.006

[18] Mainsah, E.N., Ntum, S.-J.E., Samje, M., Cho-Ngwa, F., Ndifon, P.T. and Yong, J.N. (2016) Synthesis and Anti-Onchocercal Activity of Isonicotinoylhydrazones and Their Copper(II) and Zinc(II) Complexes. Anti-Infective Agents, 14, 47-52. https://doi.org/10.2174/2211352514666151124192211

[19] Ni, W.-X., Li, M., Zhou, X.-P., Li, Z., Huang, X.-C. and Li, D. (2007) pH-Induced Formation of Metalloligand: Increasing Structure Dimensionality by Tuning Num- 
ber of Ligand Functional Sites. Chemical Communications, No. 33, 3479-3481. https://doi.org/10.1039/b705603f

[20] Ni, W.-X., Li, M., Zhan, S.-Z., Hou, J.-Z. and Li, D. (2009) In Situ Immobilization of Metalloligands: A Synthetic Route to Homometallic Mixed-Valence Coordination Polymers. Inorganic Chemistry, 48, 1433-1441. https://doi.org/10.1021/ic8015244

[21] Bernhardt, P.V., Chin, P. and Richardson, D.R. (2004) Iron Catalysed Assembly of an Asymmetric Mixed-Ligand Triple Helicate. Dalton Transactions, No. 20, 3342-3346. https://doi.org/10.1039/b408781j

[22] Bernhardt, P.V., Chin, P., Sharpe, P.C., Wang, J.-Y.C. and Richardson, D.R. (2005) Novel Diaroylhydrazine Ligands as Iron Chelators: Coordination Chemistry and Biological Activity. Journal of Biological Inorganic Chemistry, 10, 761-777. https://doi.org/10.1007/s00775-005-0018-0

[23] Sheldrick, G.M. (2001) SHELXTL, Version 6.1. Bruker AXS Inc., Maddison.

[24] Sheldrick, G.M. (1997) SHELXL97, Program for Crystal Structure Refinement. University of Gottingen, Gottingen.

[25] Mo, H.-J., Wu, J.-J., Qiao, Z.-P. and Ye, B.-H. (2012) Interaction between Biimidazole Complexes of Ruthenium and Acetate: Hydrogen Bonding and Proton Transfer. Dalton Transactions, 41, 7026-7036. https://doi.org/10.1039/c2dt30225j

[26] Wang, X.-W., Chen, F.-P., Chen, L., Chen, J.-Z., Jiang, W.-J., Cai, T.-J. and Deng, Q. (2007) Crystal Structures and Fluorescent Properties of Two Lineartrinuclear Zinc(II) Complexes. Journal of Molecular Structure, 842, 75-80.

https://doi.org/10.1016/j.molstruc.2006.12.017 